\title{
Biotransformation of a Taxadiene by Ginkgo Cell Cultures and the Tumor Multi-Drug Resistant Reversal Activities of the Metabolites
}

\author{
Dan XIE, Yi Zhang, Jianhua Zou, Dali Yin, Xiaoguang Chen, and Jungui DAI* \\ State Key Laboratory of Bioactive Substances and Functions of Natural Medicines, Institute of Materia Medica, Chinese \\ Academy of Medical Sciences \& Peking Union Medical College; 1 Xian Nong Tan Street, Beijing 100050, P. R. China. \\ Received December 22, 2010; accepted April 11, 2011; published online May 20, 2011
}

The biotransformation of $2 \alpha, 5 \alpha, 10 \beta$-triacetoxy-14-oxo-taxa-4(20),11-diene (1) by cultured Gingko cells afforded four products. Their structures were identified on the basis of analyses of the chemical and spectroscopic (IR, MS, ${ }^{1} \mathrm{H}$ - and $\left.{ }^{13} \mathrm{C}-\mathrm{NMR}\right)$ data. Among them, 2, 3 and 5 were three new compounds, and 4 displayed potent multi-drug resistant (MDR) reversal activities to MX-1/T tumor MDR cells.

Key words taxadiene; biotransformation; tumor multi-drug resistant reversal agent; Ginkgo biloba; cell suspension culture

Multi-drug resistance (MDR), the most common difficulty in the face of successful cancer chemotherapy, means a cellular resistance to structurally and functionally unrelated chemotherapeutic drugs. ${ }^{1)}$ One of the mechanisms of MDR is associated with the overexpression of P-glycoprotein (P-gp) in tumor cells, which occurs when cancer cells are exposed to a single hydrophobic cytotoxic agent. ${ }^{2,3)}$ Several generations of P-gp inhibitors, such as verapamil, quinidine, PSC833, etc., have been reported to reverse MDR in vitro and in vivo, but still failed to be developed for further clinical trials due to their unacceptable adverse effects and toxicities. ${ }^{4)}$ Therefore, searching for novel MDR reversing agents with strong potency and minimal side effects is necessary. In our previous investigation, we reported that sinenxan A and some derivatives by an enzymatic/chemical approach displayed good activities in MDR cells in vitro and in vivo. ${ }^{5-8)}$ In the enzymatical structural modification, Ginkgo cell suspension cultures were found to possess highly regio- and stereo-selective hydroxylation at the $9 \alpha$ position. ${ }^{7-10)}$ The substrate specificity of $9 \alpha$ hydroxylase of this type of taxane in Ginkgo cells has been investigated, and some "structure-activity relationships, SAR" between the enzyme and substrate structures has been concluded. ${ }^{7-11)}$ As a part of our ongoing work, in order to further investigate and better clarify the substrate specificity of the enzyme, $2 \alpha, 5 \alpha, 10 \beta$-triacetoxy14-oxo-taxa-4(20),11-diene (1), a new type of taxadiene with a carbonyl group at C-14 from sinenxan A by a chemical method has been prepared and used as a substrate. ${ }^{12)}$ In addition, another aim is to obtain more structurally diversified derivatives in the search for more valuable bioactive derivatives that act as MDR reversing agents by biotransformation. Herein, we briefly report the biotransformation of 1 by Gingko cells, the structural elucidation of new compounds, and the MDR reversal activities of metabolites towards MX1/T and MCF-7/doxorubicin (DOX) cell lines.

\section{Results and Discussion}

After incubation with cell cultures of Ginkgo for 6 d, four metabolites $\mathbf{2}-\mathbf{5}$ (Fig. 1) were obtained by the combination of open silica gel column chromatography and semi-preparative HPLC. On the basis of the IR, NMR and high resolution (HR)-MS spectral data, their structures were established to be $2 \alpha, 5 \alpha$-diacetoxy- $4 \beta, 20$-epoxy- $10 \beta$-hydroxy-14-oxo-taxa11(12)-ene (2), $2 \alpha, 5 \alpha, 10 \beta$-triacetoxy-14-oxo-taxa-4(20), 12(13)-diene (3), $2 \alpha, 5 \alpha$-diacetoxy-10 $\beta, 11$-epoxy-14-oxo-taxa$4(20), 12(13)$-diene (4), and $2 \alpha, 5 \alpha$-diacetoxy-10 $\beta, 11$ epoxy-18-hydroxy-14-oxo-taxa-4(20),12(13)-diene (5). Among these, metabolites $\mathbf{2}, \mathbf{3}$ and $\mathbf{5}$ were three new compounds. 4 had been previously obtained by chemical methods, and was the first example of a 10,11-epoxy taxoid, its physical and chemical data were in good accordance with those of the previous report. ${ }^{12)}$ In this bioprocess, we observed several reactions including hydrolysis, epoxidation, rearrangement and hydroxylation, etc. Based upon the comparison of structures of the substrate and metabolites, a plausible bioconversion pathway of $\mathbf{1}$ to the four products was proposed (Fig. 1). However, the $9 \alpha$ hydroxylation of 1 was not observed as expected in this case, indicating the high substrate specificity of $9 \alpha$ hydroxylase in Ginkgo cells, although there existed subtle substituent differences at C-14, with a carbonyl group instead of an acetoxyl or a hydroxyl group. ${ }^{8-10)}$

The positive HR-electrospray ionization (ESI)-MS spectrum of 2 showed a quasi-molecular ion peak at $\mathrm{m} / \mathrm{z}$ $457.2199[\mathrm{M}+\mathrm{Na}]^{+}$, suggesting the molecular formula to be $\mathrm{C}_{24} \mathrm{H}_{34} \mathrm{O}_{7}$. The IR absorption at $3620 \mathrm{~cm}^{-1}$ showed the presence of a hydroxyl group. Compared to 1 , the ${ }^{1} \mathrm{H}$ - and ${ }^{13} \mathrm{C}$ NMR spectra of $\mathbf{2}$ exhibited two methyl signals of acetyl moieties $\left(\delta_{\mathrm{H}} 2.06,1.98 ; \delta_{\mathrm{C}} 169.9,169.1\right.$ and $\left.21.3,20.7\right)$. The signal of $\mathrm{H}-10$ of 1 at $\delta_{\mathrm{H}} 6.12(\mathrm{dd}, J=5.4,12.0 \mathrm{~Hz})$ was shifted upfield to $\delta_{\mathrm{H}} 4.92(\mathrm{dd}, J=4.8,10.8 \mathrm{~Hz}$ ), which sug-

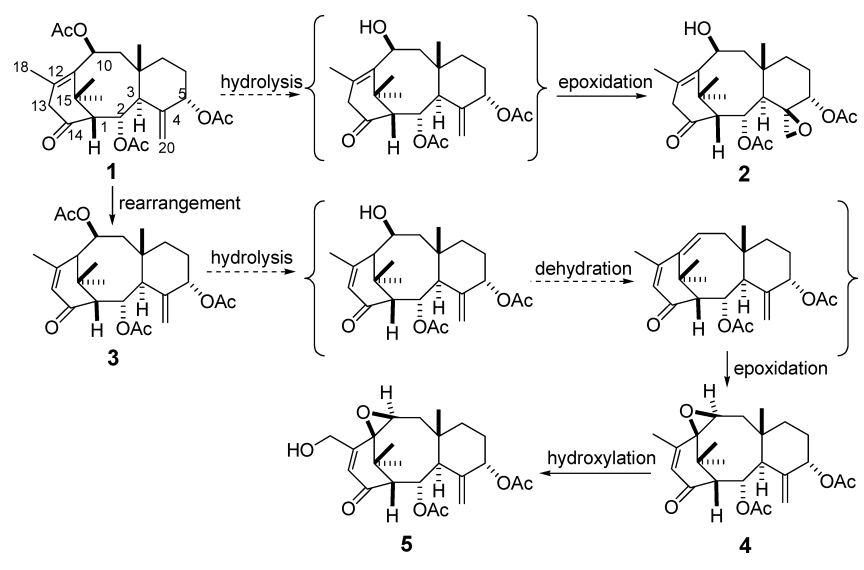

Fig. 1. A Plausible Bioconversion Pathway of $2 \alpha, 5 \alpha, 10 \beta$-Triacetoxy-14oxo-taxa-4(20),11-diene (1) with Cell Suspension Cultures of Ginkgo 
gested that a hydroxyl group rather than an acetoxyl group was present at the $\mathrm{C}-10$ position. In addition, the ${ }^{1} \mathrm{H}-\mathrm{NMR}$ spectrum displayed the disappearance of signals typically responsible for the C-4(20) exocyclic methylene proton signals at $\delta_{\mathrm{H}} 4.78(\mathrm{~s})$ and $5.25(\mathrm{~s})$ in $\mathbf{1}$, and the appearance of two doublet proton signals at $\delta_{\mathrm{H}} 3.66$ and $2.64(J=5.1 \mathrm{~Hz})$ assigned to the $\mathrm{C}-20$ methylene protons of the oxirane bridge. These observations suggested the presence of an epoxide moiety at C-4(20) instead of an exocyclic double bond. It was confirmed by the H-5 $\left(\delta_{\mathrm{H}} 3.64\right)$ of 2 resonating at an unusually high field for an acetoxylated methine of $\mathbf{1}\left(\delta_{\mathrm{H}} 5.28\right)$, and the signal of proton $\mathrm{H}-3$ was also shifted upfield to $\delta_{\mathrm{H}}$ 2.69 due to the disappearance of the exocyclic double bond. The large chemical shift difference $(\Delta \delta 1.02 \mathrm{ppm})$ between two coupling epoxide protons $\mathrm{H}-20 \mathrm{a}$ and $\mathrm{H}-20 \mathrm{~b}$ revealed that the 4(20)-expoxide group had a $\beta$-orientation. ${ }^{13)}$ Thus, the structure of 2 was identified as $2 \alpha, 5 \alpha$-diacetoxy- $4 \beta, 20$ epoxy-10 $\beta$-hydroxy-14-oxo-taxa-11(12)-ene, and its ${ }^{1} \mathrm{H}$ NMR spectroscopic data assignments are listed in Table 1.

Compound 3 was obtained as a white amorphous powder, with an elemental composition of $\mathrm{C}_{26} \mathrm{H}_{36} \mathrm{O}_{7}$, which was determined by the combined data analysis of HR-ESI-MS and ${ }^{1} \mathrm{H}$ - and ${ }^{13} \mathrm{C}$-NMR spectra. The molecular weight and molecular formula were the same as $\mathbf{1}$, and the ${ }^{1} \mathrm{H}-\mathrm{NMR}$ spectrum of $\mathbf{3}$ was very similar to $\mathbf{1}$. In comparison with the ${ }^{1} \mathrm{H}-\mathrm{NMR}$ of $\mathbf{1}$, the signal of $\mathrm{H}-10$ of $\mathbf{1}$ at $\delta_{\mathrm{H}} 6.12(\mathrm{dd}, J=5.4,12.0 \mathrm{~Hz})$ shifted upfield to $\delta_{\mathrm{H}} 5.37$ (dd, $J=3.0,12.0 \mathrm{~Hz}$ ) in 3; in addition, the typical signals of $\mathrm{H}-13$ at $\delta_{\mathrm{H}} 3.30(\mathrm{~d}, J=23.1 \mathrm{~Hz})$ and $2.65(\mathrm{~d}, J=23.1 \mathrm{~Hz})$ in 1 disappeared, while two singlet signals in 3 at $\delta_{\mathrm{H}} 6.04$ and $\delta_{\mathrm{H}} 1.70$ responsible for $\mathrm{H}-13$ and $\mathrm{H}-11$ appeared, suggesting the rearrangement of the $\mathrm{C}$ 11(12) double-bond to C-12(13). Thus, the structure of 3 was determined to be $2 \alpha, 5 \alpha, 10 \beta$-triacetoxy-14-oxo-taxa$4(20), 12(13)$-diene (3), and the assignments of its ${ }^{1} \mathrm{H}-\mathrm{NMR}$ spectroscopic data are shown in Table 1.

Compound 4 was a known compound. The stereochemistry of the epoxide ring of $\mathbf{4}$ was previously estimated by coupling constants between $\mathrm{H}-10$ and both $\mathrm{H}-9 \alpha$ and $\mathrm{H}-$
$9 \beta .^{12)}$ In this study, nuclear Overhauser effect (NOE) difference spectrum experiments have been performed. The integration values of $\mathrm{H}-9 \alpha$ and $\mathrm{H}-18$ were enhanced when $\mathrm{H}-10$ was irradiated, while the enhancement of integration values of $\mathrm{H}-9 \beta$ and $\mathrm{H}-19$ were observed when $\mathrm{H}-2$ was irradiated (Fig. 2), indicating the $\alpha$-orientation of $\mathrm{H}-10$. These results further confirmed the stereochemistry of the epoxide rings of compounds 4 (Fig. 2). Naturally occurring taxanes have $\mathrm{H}-2$ and $\mathrm{H}-19$ in the $\beta$-orientation, while $\mathrm{H}-10$ is $\alpha$-orientated. Thus, the stereochemistry of H-10 in this enzymatic product was in accordance with those natural compounds. Therefore, the structure of 4 was assigned as $2 \alpha, 5 \alpha$-diacetoxy-10 $\beta, 11$ epoxy-14-oxo-taxa-4(20),12(13)-diene.

The ${ }^{1} \mathrm{H}-\mathrm{NMR}$ spectrum of $\mathbf{5}$ was similar to that of $\mathbf{4}$, except that the signal of the 18-methyl groups at $\delta_{\mathrm{H}} 1.76(\mathrm{~s}$, $3 \mathrm{H})$ in $\mathbf{4}$ had disappeared. Meanwhile, additional coupling oxygenated methylene proton signals at $\delta_{\mathrm{H}} 4.25(\mathrm{dd}, J=1.8$, $17.1 \mathrm{~Hz})$ and $4.00(\mathrm{dd}, J=1.8,17.1 \mathrm{~Hz})$ were observed, together with two other oxygenated methines $\left[\delta_{\mathrm{H}} 5.51(\mathrm{~d}, J=\right.$ $2.7 \mathrm{~Hz}, \mathrm{H}-2)$ and $\delta_{\mathrm{C}} 70.9 ; \delta_{\mathrm{H}} 5.15(\mathrm{t}, J=3.3 \mathrm{~Hz}, \mathrm{H}-5)$ and $\delta_{\mathrm{C}}$ 64.3], suggesting a hydroxymethyl group at the C-12 (hydroxyl at C-18) position. This was supported by the fact that the signal of C-18 of 5 shifted downfield to $\delta_{\mathrm{C}} 62.3$ in the ${ }^{13} \mathrm{C}-\mathrm{NMR}$ spectrum compared with that of 4 at $\delta_{\mathrm{C}} 20.6$. Furthermore, the positive HR-ESI-MS spectrum of $\mathbf{5}$ showed a quasi molecular ion peak at $\mathrm{m} / \mathrm{z} 455.2055$, consistent with the molecular formula $\mathrm{C}_{24} \mathrm{H}_{32} \mathrm{O}_{7} \mathrm{Na}$, being 16 amu more than 4, suggesting the introduction of a hydroxyl group. This was also confirmed by the IR absorption of the hydroxyl group at $3460 \mathrm{~cm}^{-1}$. Thus, the structure of $\mathbf{5}$ was elucidated as $2 \alpha, 5 \alpha$-diacetoxy-14-oxo-10 $\beta, 11$-epoxy-18-hydroxy-taxa4(20),12(13)-diene, and its ${ }^{1} \mathrm{H}-\mathrm{NMR}$ spectroscopic data are outlined in Table 1.

$\mathbf{1}$ together with the metabolites $\mathbf{2}-\mathbf{5}$ as reversing agents, combined with taxol at $10 \mu \mathrm{M}$, were preliminarily evaluated for MDR reversal activity against the drug-resistant MX-1/T and MCF-7/DOX cell lines. The bioassay results of the tested compounds against MX-1/T and MCF-7/DOX cells are sum-

Table 1. ${ }^{1} \mathrm{H}-\mathrm{NMR}$ Spectroscopic Data for Compounds $\mathbf{1}-\mathbf{5}$ in $\mathrm{CDCl}_{3}(\delta \text { in ppm, } J \text { in Hertz })^{a)}$

\begin{tabular}{|c|c|c|c|c|c|}
\hline Position & 1 & 2 & 3 & 4 & 5 \\
\hline 1 & $2.26(\mathrm{~d}, 3.0)$ & $2.11(\mathrm{~s})$ & $2.24(\mathrm{~s})$ & $2.28(\mathrm{~s})$ & $2.32(\mathrm{~s})$ \\
\hline 2 & $5.40(\mathrm{dd}, 3.0,6.9)$ & $5.40(\mathrm{dd}, 2.7,4.8)$ & $5.50(\mathrm{~d}, 4.2)$ & $5.51(\mathrm{~d}, 2.7)$ & $5.51(\mathrm{~d}, 2.7)$ \\
\hline 3 & $3.12(\mathrm{~d}, 6.9)$ & $2.69(\mathrm{~d}, 2.7)$ & $3.19(\mathrm{~d}, 4.2)$ & $2.87(\mathrm{brs})$ & $2.86(\mathrm{brs})$ \\
\hline 5 & $5.28(\mathrm{~s})$ & $3.64(\mathrm{~m})$ & $5.12(\mathrm{brs})$ & 5.17 (brs) & $5.16(t, 3.3)$ \\
\hline 6 & $1.90-2.10(\mathrm{~m}) ; 1.82(\mathrm{~m})$ & $1.42(\mathrm{~m}, 2 \mathrm{H})$ & $1.70(\mathrm{~m}, 2 \mathrm{H})$ & $1.98(\mathrm{~m}, 2 \mathrm{H})$ & $1.72(\mathrm{~m}, 2 \mathrm{H})$ \\
\hline 7 & $\begin{array}{l}\mathrm{H} \alpha, 1.82(\mathrm{~m}) \\
\mathrm{H} \beta, 1.25(\mathrm{~m})\end{array}$ & $\begin{array}{l}\mathrm{H} \alpha, 1.83(\mathrm{~m}) \\
\mathrm{H} \beta, 1.32(\mathrm{~m})\end{array}$ & $\begin{array}{l}\mathrm{H} \alpha, 1.54(\mathrm{~m}) \\
\mathrm{H} \beta, 1.17(\mathrm{~m})\end{array}$ & $\begin{array}{l}\mathrm{H} \alpha, 1.70(\mathrm{~m}) \\
\mathrm{H} \beta, 1.25(\mathrm{~m})\end{array}$ & $\begin{array}{l}\mathrm{H} \alpha, 1.91(\mathrm{~m}) \\
\mathrm{H} \beta, 1.17(\mathrm{~m})\end{array}$ \\
\hline 9 & $\begin{array}{l}\mathrm{H} \alpha, 1.71(\mathrm{dd}, 5.4,15.0) \\
\mathrm{H} \beta, 2.46(\mathrm{dd}, 12.0,15.0)\end{array}$ & $\begin{array}{l}\mathrm{H} \alpha, 2.03(\mathrm{~m}) \\
\mathrm{H} \beta, 2.23(\mathrm{~m})\end{array}$ & $\begin{array}{l}\mathrm{H} \alpha, 1.88(\mathrm{~m}) \\
\mathrm{H} \beta, 2.43(\mathrm{dd}, 15.0,13.2)\end{array}$ & $\begin{array}{l}\mathrm{H} \alpha, 1.98(\mathrm{~m}) \\
\mathrm{H} \beta, 2.05(\mathrm{~m})\end{array}$ & $\begin{array}{l}\mathrm{H} \alpha, 1.96(\mathrm{~m}) \\
\mathrm{H} \beta, 2.03(\mathrm{~m})\end{array}$ \\
\hline $\begin{array}{l}10 \\
11\end{array}$ & $6.12(\mathrm{dd}, 5.4,12.0)$ & $4.68(\mathrm{dd}, 4.8,10.8)$ & $\begin{array}{l}5.37(\mathrm{dd}, 3.0,12.0) \\
1.70(\mathrm{~s})\end{array}$ & $2.81(\mathrm{dd}, 4.8,10.8)$ & $2.93(\mathrm{dd}, 5.1,11.1)$ \\
\hline 13 & $\begin{array}{l}3,30(\mathrm{~d}, 23.1) \\
2.65(\mathrm{~d}, 23.1)\end{array}$ & $\begin{array}{l}2.53(\mathrm{~d}, 10.5) \\
2.22(\mathrm{~d}, 10.5)\end{array}$ & $6.04(\mathrm{~s})$ & $5.94(\mathrm{~s})$ & $6.12(\mathrm{~s})$ \\
\hline 16 & $1.65(\mathrm{~s})$ & $1.22(\mathrm{~s})$ & $1.49(\mathrm{~s})$ & $1.29(\mathrm{~s})$ & $1.30(\mathrm{~s})$ \\
\hline 17 & $1.09(\mathrm{~s})$ & $1.01(\mathrm{~s})$ & $1.00(\mathrm{~s})$ & $1.21(\mathrm{~s})$ & $1.23(\mathrm{~s})$ \\
\hline 18 & $2.13(\mathrm{~s})$ & $1.25(\mathrm{~s})$ & $2.10(\mathrm{~s})$ & $1.76(\mathrm{~s})$ & $\begin{array}{l}4.28(\mathrm{dd}, 1.8,17.1) \\
4.00(\mathrm{dd}, 1.8,17.1)\end{array}$ \\
\hline 19 & $0.89(\mathrm{~s})$ & $0.89(\mathrm{~s})$ & $0.78(\mathrm{~s})$ & $0.92(\mathrm{~s})$ & $0.93(\mathrm{~s})$ \\
\hline 20 & $5.25(\mathrm{~s}) ; 4.78(\mathrm{~s})$ & $3.66(\mathrm{~m}) ; 2.64(\mathrm{dd}, 3.0,5.1)$ & $5.12(\mathrm{br} \mathrm{s}, 2 \mathrm{H})$ & $5.38(\mathrm{~s}) ; 5.17(\mathrm{~s})$ & $5.38(\mathrm{~s}) ; 5.17(\mathrm{~s})$ \\
\hline OAc & $2.09(\mathrm{~s}, 3 \times 3 \mathrm{H})$ & $2.10(\mathrm{~s}), 1.98(\mathrm{~s})$ & $2.04(\mathrm{~s}), 2.03(\mathrm{~s}), 2.00(\mathrm{~s})$ & $2.06(\mathrm{~s}), 1.89(\mathrm{~s})$ & $2.07(\mathrm{~s}), 1.91(\mathrm{~s})$ \\
\hline
\end{tabular}




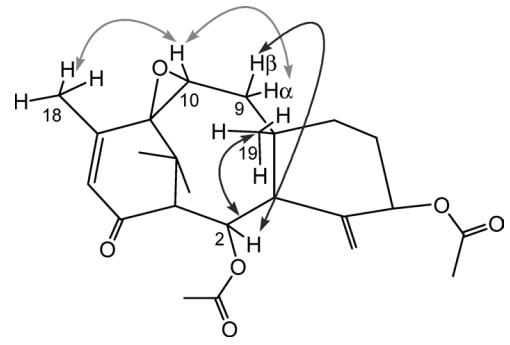

Fig. 2. Key NOE Correlations $(\leftrightarrow)$ of $\mathbf{4}$

Table 2. MDR Reversal Activities of Compounds 1-5 against MDR Sublines of Taxol-Resistant MX-1 and Doxorubicin-Resistant MCF-7 Cell Lines in Vitro ${ }^{a, b)}$

\begin{tabular}{ccc}
\hline \hline Compounds & $\begin{array}{c}\mathrm{MCF}-7 / \mathrm{DOX} \\
\mathrm{IC}_{50}(\mu \mathrm{M})^{c)}\end{array}$ & $\begin{array}{c}\mathrm{MX}-1 / \mathrm{T} \\
\mathrm{IC}_{50}(\mu \mathrm{M})^{c)}\end{array}$ \\
\hline Taxol+1 & $>500$ & $>500$ \\
$\mathbf{2}$ & $>500$ & $>500$ \\
$\mathbf{3}$ & $>500$ & $>500$ \\
$\mathbf{4}$ & $>500$ & 2.24 \\
$\mathbf{5}$ & $>500$ & $>500$ \\
Taxol (control) & $>500$ & $>500$ \\
\hline
\end{tabular}

a) MCF-7/DOX: human breast cancer cell line resistant to doxorubicin, MX-1/T human breast carcinoma cell line resistant to taxol. b) Four varieties of taxol concentration were administered in the experiment at $10^{-9}, 10^{-8}, 10^{-7}$, and $10^{-6} \mathrm{M}$, the reversal agents concentration were administered at $10 \mu \mathrm{M}$. c) $\mathrm{The}^{-\mathrm{IC}_{50}}$ values defined as the taxol concentration that resulted in a $50 \%$ reduction in the number of cells compared with control cells, was the means of triplicates.

marized in Table 2. Among all the tested compounds, $\mathbf{1}-\mathbf{3}$ and $\mathbf{5}$ exhibited substantially weak reversing activities, while compound 4 displayed potent effects against MX-1/T cells. The $\mathrm{IC}_{50}$ value of taxol co-administered with the reversal agent 4 at $10 \mu \mathrm{M}$ decreased to $2.22 \mu \mathrm{M}$ from $>500 \mu \mathrm{M}$.

In this paper, cell suspension cultures of G. biloba were employed to convert a taxadiene derived from the natural product sinenxan A to four structurally diversified metabolites (2-5) via different reactions, such as hydrolysis, epoxidation, rearrangement and hydroxylation, etc. The characteristic C-9 $\alpha$ hydroxylation of sinenxans by Ginkgo cells did not occur as expected, indicating the narrow substrate specificity of $9 \alpha$ hydroxylase, even toward compounds with subtle structural differences. Furthermore, among these compounds, 4 exhibited greatly significant MDR reversal activity to $\mathrm{MX}-1 /$ Taxol cells, far more potent than $\mathbf{1}$ and the other metabolites, suggesting 4 might be a good lead as an MDR reversal agent. In summary, these results showed that biotransformation is a powerful approach to compound structural diversification, and valuable in the process of drug R \& D.

\section{Experimental}

General Experimental Procedures Optical rotations in $\mathrm{CHCl}_{3}$ were carried out using a Perkin-Elmer Model-343 digital polarimeter. IR spectra were obtained using a Thermo-Nicolet 5700 spectrophotometer. The ${ }^{1} \mathrm{H}-$, ${ }^{13} \mathrm{C}$-NMR and NOE difference spectra were recorded in $\mathrm{CDCl}_{3}$ on Mercury300 and Varian-400 spectrometers using visual resonances $\left({ }^{1} \mathrm{H} \delta 7.27,{ }^{13} \mathrm{C} \delta\right.$ $77.0)$ as an internal reference. Chemical shifts $(\delta)$ were given in ppm, coupling constants $(J)$ were given in hertz $(\mathrm{Hz})$. HR-ESI-MS were obtained on a Q-trap ESI mass spectrometer. Normal-phase semi-preparative HPLC was performed on a Shiseido HPLC instrument equipped with a YRU-883A $\mathrm{RI} / \mathrm{UV}$-bidetector and a YMC Prep-Si stainless steel column $(5 \mu \mathrm{m}, 250$ $\mathrm{mm} \times 10 \mathrm{~mm}$ i.d., YMC Co., Ltd., Tokyo, Japan) by eluting with the mixtures of $n$-hexane and ethyl acetate (flow rate $4 \mathrm{ml} / \mathrm{min}$ ). Silica gel (300400 mesh, Qingdao Marine Chemical Industry, Qingdao, P. R. China) was employed for column chromatography, and analytical TLC was carried out on pre-coated Si gel GF-254 plates (Qingdao Marine Chemical Industry). The visualization of TLC plates was performed by illuminating at UV $254 \mathrm{~nm}$, and by spraying with $5 \% \mathrm{H}_{2} \mathrm{SO}_{4}$ in EtOH followed by heating at $105^{\circ} \mathrm{C}$.

Substrates and Organism, Media and Cultivation Conditions $2 \alpha, 5 \alpha, 10 \beta$-Triacetoxy-14-oxo-taxa-4(20),11-diene (1), was prepared as described in the literature. ${ }^{12)}$ The cell suspension cultures of Ginkgo biloba were cultivated in a $1000 \mathrm{ml}$ Erlenmeyer flask with $330 \mathrm{ml}$ liquid MS media, which was supplemented with $0.5 \mathrm{mg} / 1$ of naphthalene acetic acid (NAA), $0.5 \mathrm{mg} / 1$ of 6-benzylaminopurine (6-BA) and $0.2 \mathrm{mg} / 1$ of 2,4-dichlorophenoxy acetic acid (2, 4-D). The medium $\mathrm{pH}$ was adjusted to 5.8 before autoclaving at $121^{\circ} \mathrm{C}$ for $25 \mathrm{~min}$. The cultivation procedure was carried out with an inoculum size of $5 \mathrm{~g} / 1$ of cell cultures which were shaken at $110 \mathrm{rpm}$ at $(25 \pm 2)^{\circ} \mathrm{C}$ in the dark as described previously. ${ }^{14)}$

Biotransformation and Separation The substrate $(1,500 \mathrm{mg})$ was dissolved in $10 \mathrm{ml} \mathrm{EtOH}$ before use, then uniformly distributed at a final concentration of $50 \mathrm{mg} / 1$ among 30 flasks of 15 -d-old cell cultures. After an additional $6 \mathrm{~d}$ of incubation, the cultures were filtered under reduced pressure, and the filtrate was extracted with ethyl acetate four times. All the extracts were pooled, dried with anhydrous $\mathrm{Na}_{2} \mathrm{SO}_{4}$, and concentrated under a vacuum at $40^{\circ} \mathrm{C}$ to give $950 \mathrm{mg}$ of residue. The dried cell cultures $(120 \mathrm{~g})$ were extracted three times in an ultrasonic bath by an equivalent volume of acetone, and the resulting extracts were pooled and concentrated under a vacuum at $40{ }^{\circ} \mathrm{C}$ to afford $300 \mathrm{mg}$ of residue. The above two extracts were combined and separated by a combination of open silica gel chromatography and semi-preparative HPLC [mobile phase: $n$-hexane/ethyl acetate $(80 / 20, \mathrm{v} / \mathrm{v})$ ] to afford 1 (110 mg, ca. 22\%; analyzed by TLC and $\left.{ }^{1} \mathrm{H}-\mathrm{NMR}\right), 2$ (20.6 mg, ca. $5 \%$; $\left.t_{\mathrm{R}} 16 \mathrm{~min}\right), 3\left(9.0 \mathrm{mg}, t_{\mathrm{R}} 8.5 \mathrm{~min}\right), 4\left(181.3 \mathrm{mg}, c a .36 \% ; t_{\mathrm{R}} 12 \mathrm{~min}\right)$, and $\mathbf{5}\left(6.7 \mathrm{mg}, t_{\mathrm{R}} 19 \mathrm{~min}\right)$.

$2 \alpha, 5 \alpha$-Diacetoxy-4 $\beta, 20$-epoxy-10 $\beta$-hydroxy-14-oxo-taxa-11(12)-ene (2): Colorless amorphous powder. ${ }^{1} \mathrm{H}-\mathrm{NMR}$ spectral data see Table $1 .{ }^{13} \mathrm{C}-\mathrm{NMR}$ $\left(\mathrm{CDCl}_{3}, 100 \mathrm{MHz}\right) \delta: 206.9(\mathrm{C}-14), 170.1$ and $169.3\left(2-\mathrm{CH}_{3} \mathrm{CO}\right.$ and 5$\left.\mathrm{CH}_{3} \mathrm{CO}\right), 125.1$ (C-11), 116.5 (C-12), 77.2 (C-5), 73.6 (C-2), 61.6 (C-10), 58.9 (C-20), 54.6 (C-4), 52.4 (C-13), 51.7 (C-1), 47.9 (C-3), 45.7 (C-8), 43.1 (C-15), 42.3 (C-9), 35.8 (C-7), 35.1 (C-17), 26.7 (C-6), 25.7 (C-16), 23.7 (C-18), $22.5(\mathrm{C}-19), 21.3$ and $21.2\left(2-\mathrm{CH}_{3} \mathrm{CO}\right.$ and $\left.5-\mathrm{CH}_{3} \mathrm{CO}\right)$. IR $(\mathrm{KBr})$ $\mathrm{cm}^{-1}: 3452,2969,2930,1730,1672,1232,1018,962$. Positive HR-ESI-MS $m / z: 457.2199[\mathrm{M}+\mathrm{Na}]^{+}$(Calcd for $\left.\mathrm{C}_{24} \mathrm{H}_{34} \mathrm{O}_{7} \mathrm{Na}: 457.2202\right) .[\alpha]_{\mathrm{D}}^{25}+41.9$ $\left(c=0.12, \mathrm{CHCl}_{3}\right)$.

$2 \alpha, 5 \alpha, 10 \beta$-Triacetoxy-14-oxo-taxa-4(20),12(13)-diene (3): White amorphous powder. ${ }^{1} \mathrm{H}-\mathrm{NMR}$ spectral data see Table $1 .{ }^{13} \mathrm{C}-\mathrm{NMR}\left(\mathrm{CDCl}_{3}\right.$, $100 \mathrm{MHz}) \delta$ : $198.8(\mathrm{C}-14), 170.1,169.7$ and $169.6\left(2-\mathrm{CH}_{3} \mathrm{CO}, 5-\mathrm{CH}_{3} \mathrm{CO}\right.$ and $\left.10-\mathrm{CH}_{3} \mathrm{CO}\right), 163.5(\mathrm{C}-12), 141.1(\mathrm{C}-4), 128.5$ (C-13), 117.5 (C-20), 78.9 (C-5), 73.3 (C-2), 69.9 (C-10), 65.9 (C-11), 60.1 (C-1), 55.7 (C-15), 51.9 (C-3), 45.3 (C-8), 40.3 (C-9), 37.8 (C-7), 34.8 (C-17), 27.9 (C-6), 25.9 (C-16), $24.6(\mathrm{C}-18), 23.4\left(10-\mathrm{CH}_{3} \mathrm{CO}\right), 21.5$ and $21.4\left(2-\mathrm{CH}_{3} \mathrm{CO}\right.$ and 5$\left.\mathrm{CH}_{3} \mathrm{CO}\right), 20.5$ (C-19). IR (KBr) cm${ }^{-1}: 2969,2930,1730,1669,1368,1232$, 1018, 963. Positive HR-ESI-MS $m / z$ : $483.2349[\mathrm{M}+\mathrm{Na}]^{+}$(Calcd for $\left.\mathrm{C}_{26} \mathrm{H}_{36} \mathrm{O}_{7} \mathrm{Na}: 483.2353\right)$. $[\alpha]_{\mathrm{D}}^{25}+82.5\left(c=0.11, \mathrm{CHCl}_{3}\right)$.

$2 \alpha, 5 \alpha$-Diacetoxy-10 $\beta, 11$-epoxy-14-oxo-taxa-4(20),12(13)-diene (4): Colorless amorphous powder. ${ }^{1} \mathrm{H}-\mathrm{NMR}$ spectral data see Table $1 .{ }^{13} \mathrm{C}-\mathrm{NMR}$ $\left(\mathrm{CDCl}_{3}, 100 \mathrm{MHz}\right) \delta$ : $197.1(\mathrm{C}-14), 169.9$ and $169.3\left(2-\mathrm{CH}_{3} \mathrm{CO}, 5-\mathrm{CH}_{3} \mathrm{CO}\right)$, 137.4 (C-12), 130.7 (C-11), 130.1 (C-4), 114.1 (C-20), 78.9 (C-10), 73.3 (C2), 69.9 (C-5), 65.2 (C-11), 64.2(C-10), 60.8 (C-1), 44.1 (C-3), 40.8 (C-8), 38.8 (C-15), 38.5 (C-9), 32.9 (C-7), 29.5 (C-17), 27.9 (C-6), 22.4 (C-16), 21.4 and $21.1\left(2-\mathrm{CH}_{3} \mathrm{CO}\right.$ and 5- $\left.\mathrm{CH}_{3} \mathrm{CO}\right), 20.6(\mathrm{C}-18), 16.7(\mathrm{C}-19)$. IR (KBr) $\mathrm{cm}^{-1}:$ 2958, 2932, 2873, 1735, 1666, 1371, 1231, 1031, 894, 805. Positive HR-ESI-MS $m / z$ : $439.2087[\mathrm{M}+\mathrm{Na}]^{+}\left(\mathrm{Calcd}\right.$ for $\mathrm{C}_{24} \mathrm{H}_{32} \mathrm{O}_{6} \mathrm{Na}: 439.2091$ ). $[\alpha]_{\mathrm{D}}^{25}+62.5\left(c=0.11, \mathrm{CHCl}_{3}\right)$.

$2 \alpha, 5 \alpha$-Diacetoxy-10 $\beta, 11$-epoxy-18-hydroxy-14-oxo-taxa-4(20),12(13)diene (5): White amorphous powder. ${ }^{1} \mathrm{H}-\mathrm{NMR}$ spectral data see Table $1 .{ }^{13} \mathrm{C}$ NMR $\left(\mathrm{CDCl}_{3}, 100 \mathrm{MHz}\right) \delta: 197.2(\mathrm{C}-14), 169.9$ and $169.6\left(2-\mathrm{CH}_{3} \mathrm{CO}, 5-\right.$ $\left.\mathrm{CH}_{3} \mathrm{CO}\right), 163.3$ (C-12), 141.0 (C-4), 125.9 (C-13), 117.5 (C-20), 71.5 (C-5), 71.0 (C-2), 64.6 (C-11), 64.3 (C-10), 62.3 (C-18), 60.3 (C-1), 44.2 (C-3), 40.9 (C-8), 38.9 (C-15), 38.5 (C-9), 32.9 (C-7), 29.7 (C-17), 28.0 (C-6), 22.2 (C-16), 21.3 and $21.2\left(2-\mathrm{CH}_{3} \mathrm{CO}\right.$ and $\left.5-\mathrm{CH}_{3} \mathrm{CO}\right), 20.6(\mathrm{C}-19)$. IR ( $\left.\mathrm{KBr}\right)$ $\mathrm{cm}^{-1}$ : 3460, 2958, 2933, 2873, 1733, 1664, 1373, 1230, 1022, 959, 897. Positive HR-ESI-MS $m / z$ : $455.2055[\mathrm{M}+\mathrm{Na}]^{+}$(Calcd for $\mathrm{C}_{24} \mathrm{H}_{32} \mathrm{O}_{7} \mathrm{Na}$ : 455.2046). $[\alpha]_{\mathrm{D}}^{25}+74\left(c=0.12, \mathrm{CHCl}_{3}\right)$.

Evaluation of MDR Reversal Activity for Compounds $1-5$ in Vitro The human breast cancer cell line MCF-7 and human breast carcinoma cell line MX-1 were maintained in the Department of Pharmacology, Institute of Materia Medica, Chinese Academy of Medical Sciences and Peking Union 
Medical College. The drug-resistant sublines of MCF-7/DOX and MX-1/T were established by culturing the cells with gradually increasing concentrations of DOX or taxol, and identified with molecular techniques. ${ }^{15)}$ The MDR tumor cells were incubated in RPMI 1640 medium supplemented with $10 \%$ fetal bovine serum (FBS), $100 \mathrm{U} / \mathrm{ml}$ of penicillin and $100 \mu \mathrm{g} / \mathrm{ml}$ of streptomycin at $37^{\circ} \mathrm{C}$ in a humidified atmosphere of $5 \% \mathrm{CO}_{2}$ in air. Cells were subcultured twice every week by digestion with mixture of $0.25 \%$ trypsin and $0.01 \%$ ethylenediaminetetraacetic acid (EDTA) solution. The procedures were performed as described in the literature. ${ }^{16)}$ Reversing agents $(10 \mu \mathrm{M})$ combined with taxol $(1,0.1 \mu \mathrm{M}, 10,1 \mathrm{~nm})$ were dissolved in $100 \mu \mathrm{l}$ dimethyl sulfoxide (DMSO) with a final DMSO concentration of $0.1 \%$ in each well. Each concentration was tested in three parallel wells, and was treated in MCF-7/DOX and MX-1/T cells to detect the reversal activities of these agents in those resistance cells. $\mathrm{The} \mathrm{IC}_{50}$ values were defined as the taxol concentration that resulted in a $50 \%$ reduction in the number of cells compared with control cells after $4 \mathrm{~d}$ of incubation, and were determined directly from the semi-logarithmic dose-response curves.

Acknowledgments This work was supported by the National Natural Science Foundation of China (Grant No. 30772736), the Program for New Century Excellent Talents in University (NCET-06-0155), and the National Science \& Technology Major Project 'Key New Drug Creation and Manufacturing,' China (No. 2009ZX09103-033).

\section{References}

1) Ueda K., Pastan I., Gottesman M. M., J. Biol. Chem., 262, 17432 17436 (1987).
2) Gottesman M. M., Annu. Rev. Med., 53, 615-627 (2002).

3) Gottesman M. M., Pastan I., Annu. Rev. Biochem., 62, 385-427 (1993).

4) Ford J. M., Hait W. N., Pharmacol. Rev., 42, 155-199 (1990).

5) Hasegawa T., Bai J., Dai J., Bai L., Sakai J., Nishizawa S., Bai Y., Kikuchi M., Abe M., Yamori T., Tomida A., Tsuruo T., Hirose K., Ando M., Bioorg. Med. Chem. Lett., 17, 3722-3728 (2007).

6) Dai J., Qu R., Zou J., Chen X., Tetrahedron, 64, 8102-8116 (2008).

7) Zou J., Du H., Zhang Y., Dai J., Yin D., Chen X., J. Mol. Catal., B Enzym., 55, 12-18 (2008).

8) Dai J., Curr. Top. Med. Chem., 9, 1625-1635 (2009).

9) Dai J., Guo H., Lu D., Zhu W., Zhang D., Zheng J., Guo D., Tetrahedron Lett., 42, 4677-4679 (2001).

10) Dai J., Zhang M., Ye M., Zhu W., Guo J., Liang X., Chin. Chem. Lett., 8, 804-806 (2003)

11) Zhan Y., Zou J., Ma X., Dai J., J. Mol. Catal., B Enzym., 36, 43-46 (2005).

12) Huang G., Guo J., Liang X., Chin. Chem. Lett., 8, 277-280 (1997).

13) Hosoyama H., Shigemori H., In Y., Ishida T., Kobayashi J., Tetrahedron, 54, 2521-2528 (1998).

14) Dai J., Zhu W., Wu Y., Hu Q., Zhang D., Acta Pharmacol. Sin., 35, $151-155$ (2000).

15) Zhang Y., Li H., Wang H., Su F., Qu R., Yin D., Dai J., Li Y., Chen X., Cancer Chemother. Pharmacol., 66, 851-859 (2010).

16) Green L. M., Reade J. L., Ware C. F., J. Immunol. Methods, 70, 257268 (1984). 